\title{
HASHIMOTO SANAI: A JAPANESE MARTYR
}

\author{
By Frederick Welden
}

Frederick Welden, a Rutgers graduate of the class of 1934, taugbt in the Oita College of Commerce in Fapan during the years 1936 to 1939 and is now a graduate student in the Department of Cbinese and Fapanese at Columbia University. He bas been given a grant from the American Council of Learned Societies to catalogue the Far Eastern Section of the Griffis collection in the Rutgers Library. In the following article be discusses a Fapanese manuscript in the possession of the Library and gives a translation of parts of it which bave an interesting bearing on the rise of modern fapan.

S IS commonly known, the modernization of Japan and her subsequent rise as a world power have been comparatively recent developments. From 1603 until I 868, the so-called Tokugawa period, the political, social, and economic structure of that country was of a distinctly feudal nature, and during most of this era all intercourse with Western traders, missionaries, and governments was repeatedly forbidden by Japanese law. Dutch traders alone - more specifically, traders in the employ of the Dutch East India Company-were exempted, but only under such numerous and unfair conditions as to leave them with little or no voice in the actual conduct and control of trade.

During these two and a half centuries government took the form of an hereditary military dictatorship dominated by the powerful Tokugawa clan, whose headquarters was in Edo, site of the present-day Tókyo. ${ }^{1}$ The imperial family, dwelling in the ancient capital of Kyōto in central Japan, retained certain traditional functions of minor importance, but was to all intents and purposes at the mercy of the Tokugawa.

By the middle of the nineteenth century corruption and incompetence in the Tokugawa line had already permitted defects inherent within their administrative system to come to the surface. This condition, together with the pressure exerted by some of the more influential provincial lords to restore imperial rule and the even more significant pressure of major

${ }^{1}$ The two Chinese characters for Tōkyō (東京) literally mean “Eastern Capital." 
Western powers to force diplomatic and commercial intercourse upon Japan, finally resulted in a successful revolution and the restoration of the imperial form of government in I868.

The first emperor of this modern era is known as Meiji, renowned for the progressive and cosmopolitan character of his reign. In his Charter Oath, in particular, one of five points provided that "wisdom and learning should be sought after in all quarters of the world for the purpose of firmly establishing the foundations of the empire."

It was in observance of this imperial edict that one Matsudaira Shungaku, ${ }^{2}$ governor of the central province of Echizen, immediately directed his aides to seek an American teacher who could supervise the establishment of a school of American pattern in Fukui, the provincial capital. This teacher, employed in New York in I870, was William Elliott Griffis, a graduate of Rutgers in the Class of 1869 , who thereby became the first American to go out to Japan as an employee of the Japanese government.

Though he resided in Japan only four years (I870-74), Griffis never abandoned his many connections there, nor did his interest in and endeavors for friendly Japanese-American relations ever cease. Upon his death in I928, a very considerable quantity of his books and papers, among them many pertaining to the Far East, passed to the Rutgers University Library, where they are still in process of being cataloged.

The Japanese manuscript with which we are here concerned was prepared especially for Dr. Griffis in 1907 by a brother and several friends of Hashimoto Sanai (橋本左內). ${ }^{3}$ Its value may be explained on two grounds: In the first place, nothing of Sanai's early life has as yet been published in any Western language; while the best of our modern studies on Japan pay considerable tribute to him as a liberal, they record only the

2 Matsudaira Shungaku (松平春获, I829-90), sometimes known as Matsudaira Yoshinaga or Keiei (慶永), figured prominently in the Restoration of 1868 , as will be seen in the course of this article.

It should perhaps be mentioned that in both Chinese and Japanese the surname is written before the given name, the latter being used in subsequent references to the person.

${ }^{3}$ The foregoing fact, derived from correspondence between Griffis and Hashimoto Tsunatsune, is significant in establishing the general background and authenticity of the manuscript. It should also be mentioned that a Japanese-made English translation accompanied the original work and, though incorrect or strangely rendered in places, has proved very useful to the present translator. 
events of the last few years of his life. Secondly, this biographical sketch indicates a few of the many problems confronting Japanese reformers of the mid-nineteenth century and shows how close the Japanese were to bursting the shackles of isolation even before Commodore Perry sailed into Edo Bay in 1853. Sanai was a martyr, and in the light of present-day world turmoil the story of any martyr is perhaps doubly appreciated. The translation of the manuscript follows.

\section{A Biograpbical Sketcb of Hasbimoto Sanai}

Hashimoto Sanai was born in the section called Tokiwa-machi of the city of Fukui, Echizen province, on the eleventh day of the third month of I 834. His father, Nagatsuna by name, was a man of considerable talent who served as physician in the court of the lord of Echizen. His ancestors belonged to the Momonoi family, near relations of the famous Ashikaga. ${ }^{4}$

Sanai was clever by nature and loved learning. He studied Chinese classics and history under the guidance of Yoshida Tōkō, ${ }^{5}$ a noted scholar of the Fukui clan ... In appearance he was of rather short stature and fair countenance, looking more like a young woman than a man. His admiration for the character of Yo Fei, ${ }^{6}$ the Chinese patriot of the Sung dynasty, led him to assume in his early writings the nom de plume of Keigaku, or "Yo Fei admirer." He studied medicine and frequently practised in place of his father. Although very young, he is said to have been skilled in surgery, his father probably having been his sole teacher.

One day in his fifteenth year he remarked: "If I continue in this remote corner of Japan, I shall be unable to free myself from the narrow views incidental to these rural surroundings. I ought to study under a noted person in one of the principal cities of Japan." And so, crossing the island to Ōsaka, he studied Western learning and medicine under Ogata Kōan. ${ }^{7}$

In $185 \mathrm{I}$, at the age of seventeen, he was obliged to return to Fukui on account of his father's illness, and the following year he had to take over the latter's practice because of his death. In I 854 he went to Edo to study

4 The Ashikaga (足利) was one of the branch families of the Minamoto (源), who in turn stemmed from the imperial line, and had held secular rule during the period I336-I 573 . E. Papinot, Dictionnaire d'Histoire et de Géograpbie du Fapon, Yokohama, Igo6, p. 30.

5 吉田東管, I808-75.

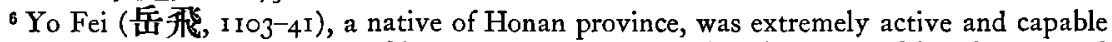
as a military leader against the Tartar invaders. Though imprisoned on false charges and summarily executed by treacherous civil officials in I I4I, he was canonized by the Chinese emperor in II 79 and today still ranks high among China's heroes. $\mathrm{H}$. A. Giles, $A$ Cbinese Biograpbical Dictionary, London, I898, pp. 949-50.

7 “In I 838 Dr. Ogata [緒方洪戻] established his school in Ōsaka, and in the twenty-four years of its existence, 3,000 pupils passed through it. Among them were such men as Omura Masujirō, Hashimoto Sanai, Fukuzawa Yukichi,... all of whom afterwards became prominent figures in modern Japanese history, but not one attained fame through his medical acquirements." J. Murdoch, A History of Japan, Kōbe and New York, I903-26, III, 565. 
under the direction of Sugita Seikei. ${ }^{8}$ When he first met Seikei, the latter gave him a Dutch book to be learned by heart. Sanai studied very diligently and mastered it all in a month's time, much to the astonishment of Seikei, who thereupon declared that Sanai must become his successor. The next year, however, after having studied Chinese classics at the school of Shionoya Töin and Yasui Sokken, Sanai returned to Fukui.

Matsudaira Shungaku, the lord of his clan, came to know of his case and shortly afterwards, having freed him from his responsibilities as court physician, sent him to Edo once more to complete his education. During this period Sanai acquired a thorough knowledge of foreign [i.e. European] countries and associated himself with the outstanding Japanese of the time. Moreover, as he broadened his knowledge and experience, he became conscious of a mightier purpose and it was at this juncture that he resolved to sacrifice himself for his country.

At one time Sanai had stated: "To think highly of the manners and loyalty of the samurai ${ }^{9}$ has been the principle of our state since ancient times. If we remain faithful to samurai customs, it is evident that the manners of the people will become pure and simple, the soul of a samurai will be developed, and the condition of the country will become superior to that of any other land. We need not adopt the ways of China nor imitate the methods of the Dutchmen." From this we can see how highly he esteemed the native state of affairs in Japan . . ..$^{10}$

In 1856 the lord of Echizen established an academy in Fukui. It was his intention to appoint Sanai director, but the latter, declining the offer, explained that he desired another ten years in which to complete his studies in science and philosophy. In spite of this reply his lord insisted upon Sanai's return, and so he obeyed the command and was duly entrusted with the post of director of the provincial academy.

Students of those days were prone to discuss matters but to neglect their practical solution. Accordingly Sanai announced that henceforth his students must study literature and at the same time practise the military arts. Assisted by an able staff of young progressives, he devoted himself to the reformation of the existing educational system, ${ }^{11}$ with the result that a real zest for learning was promptly aroused throughout the province.

Sanai took the academy of the Mito clan, ${ }^{12}$ known as the Kōdokan, for his model, and even adopted some of its regulations. The principles of the new school were loyalty and obedience, after the doctrine of Fujita Tōkō. ${ }^{13}$

${ }^{8}$ Sugita Seikei (杉田成卿) was a noted scholar and physician of the Dutch school.

$\checkmark$ Feudal military retainers who constituted the lesser nobility.

${ }^{10}$ The drastic change in Sanai's attitude towards Western civilization is revealed in the paragraphs which follow. See also p. 20.

${ }^{11}$ For several centuries educational institutions in Japan had been founded and conducted along Chinese lines. Students were from noble families and spent most of their time memorizing and interpreting Chinese literature, history, and philosophy.

${ }^{12}$ The Mito (水戶) was one of the three branch families of the Tokugawa established early in the seventeenth century to provide an heir in case of failure of the main line.

${ }^{13}$ Fujita Tōko (藤田東湖, 1806-55) was a samurai and scholar, probably the leading intellectual of the Mito clan at the time. He served as chief councilor to his lord and bent his 
It is also noteworthy that Sanai, reversing his previous position, came to introduce certain courses of European learning into the academy: mathematics, industrial arts, and military arts, for example.

In accordance with his other plans a steamship was purchased, the manufacture of small arms, cannon, and gunpowder was begun, mining operations were undertaken, and the sea coast of Echizen was surveyed. ${ }^{14}$ He saw to it that every phase of these developments was directed by suitable persons and himself diligently studied the defense of the province. $\mathrm{He}$ encouraged both industry and agriculture and advocated the reform of commercial ethics. He also did his utmost to have Yokoi Shōnan properly employed in his clan. ${ }^{15}$

In 1857 , his lord being then resident in Edo and having summoned him, Sanai once more journeyed eastward. There he was appointed personal adviser to the lord and so came to participate in affairs of state.

A short time before [1853] Commodore Perry had put in at Uraga Bay and demanded the opening of the ports. There ensued considerable tumult in every part of Japan; moreover, the policies of the Tokugawa government at Edo and those of the imperial court in Kyōto were not in agreement. At about the same time Iesada, thirteenth of the Tokugawa rulers, fell seriously ill, and there was no successor for him. ${ }^{16}$ Leaders from several of the chief clans held a consultation and decided that the "prince" Hitotsubashi Keiki should be chosen heir of Iesada inasmuch as he was very clever and extremely popular with the people. ${ }^{17} \mathrm{By}$ means of this succession they hoped to settle such problems as treaties with foreign nations and the opening of the ports and, in addition, to bring both the Kyōto court and Edo government into agreement.

The Tokugawa regime, these clan leaders thought, should no longer be left free to exercise dictatorial powers, and since Sanai's own lord, together with the influential lords of Mito and Tosa, concurred in this view, Sanai and other liberal leaders from such clans as Mito, Satsuma, Tosa, and Yanagawa did their utmost to bring the matter to this conclusion. ${ }^{18}$

efforts towards (I) restoration of the imperial rule, (2) revival of the ancient discipline through Shintoism, and (3) active repulsion of Western intercourse by means of increased national defense. Cf. Murdoch, op. cit. III, 457-66.

14 The reader is reminded that for over two centuries the Tokugawa government had pursued an isolationist policy. Such modern developments as are mentioned above remained either unused or unknown in feudal Japan until the need for them was demonstrated by the invasions of Western missions in the early and middle nineteenth century.

${ }^{15}$ Yokoi Shōnan (橫井小楠, I 809-69) was a samurai from the Kumamoto clan in western Kyūshū, renowned for his liberalism at the time of the imperial restoration. His reward was assassination by political enemies. Cf. Papinot, op. cit., p. 888.

${ }^{16}$ I.e., in direct line.

${ }^{17}$ Hitotsubashi Keiki (一橋慶喜, I837-1913) was eligible for the post inasmuch as both his own and adopted families were branch families of the Tokugawa. The reader will be interested to know that Keiki became the fifteenth and last ruler of the Edo government in I866; under the name of Tokugawa Keiki or Tokugawa Yoshinobu he ruled until 1868.

18 The Mito resided in Hitachi province, along the northeast coast of the main island, the Tosa in the province of the same name on the central island called Shikoku, the Satsuma in their own large province at the southern tip of the island of Kyūshū, and the Yanagawa in the province of Chikugo, in northwestern Kūyshū. The Japanese manuscript provides the 
It is clear that Sanai entertained ideas favoring the establishment of a ministerial form of government with "Prince" Keiki at the head. ${ }^{19}$ Again, he once stated that Japan "should hire fifty teachers of arts and sciences from Russia and America, and ought to transplant foreign knowledge. Thus in military and naval affairs, navigation, commerce, industry, agriculture, etc., we must not be inferior to foreign countries."

With regard to foreign relations and, in particular, the eastward advance of the British, he proposed that Japan should seek safety in an alliance with Russia.

"Considering the present state of the world, the country which will gain supremacy over the world will, in all probability, be either England or Russia . . . England is exceedingly avaricious. She has annexed India and threatened China. On the other hand Russia seems righteous and honest. She is a good neighbor with much the same interests as ours, and therefore we must form a close association with her."'20

Sanai also believed that Japan, in order to maintain her independence, would have to take possession of Korea, Manchuria, and the eastern maritime provinces of Siberia and, above all else, would need colonies in India and America. It was likewise his opinion that Japan would come to play her rôle in the world's drama only by means of such steps and that it was essential to place "Prince" Keiki at the helm of the Edo government.

In the spring of I $85^{8,21}$ Sanai made his way southward to Kyöto and held secret interviews with Sanjo Sanemitsu, then Lord Chamberlain in the imperial court. Subsequently he was presented to His Imperial Highness Prince Seiren-in and to several other influential members of the court. Having secured their support, he submitted to the emperor a petition requesting that the Kyōto court (a) should direct "Prince" Keiki to assume the leadership of the Edo government, and (b) should itself conclude suitable treaties with foreign countries. ${ }^{22}$ He remained in Kyoto three months striving to attain this object and then returned to Edo, there to devote himself with renewed vigor to the national cause.

In the meantime Ii Naosuke, ${ }^{23}$ then prime minister in the Edo government, disdaining all other opinions and disregarding the instructions of

names of several of these leaders: Takeda Kōunsai, Harada Hachibei, Harada Seinojō, Sakura Jinzō, Saigō Takamori, Tachibana Iki, et al.

${ }_{19}$ This fact may be deduced from one of Sanai's commentaries on domestic affairs, recorded on pp. Io-1 2 in the Japanese manuscript.

${ }_{20}$ A Japanese encyclopedia records this statement under the year 1857. Cf. Dai Hyakka Fiten (大百科事典), Tōkyō, 1934, XX, 632 .

${ }^{21}$ Sanai was then in his twenty-fourth year.

22 To appreciate the full significance of this effort on the part of Sanai the reader must realize that, except for occasional and relatively brief lapses, the actual power of government in Japan had rested for almost seven centuries in the hands of military rulers (called sboguns) or those about them, and not in the imperial family.

${ }^{23}$ Ii Naosuke (井伊直焗, I815-60) was virtually premier-dictator from $185^{8}$ until his assassination two years later. It was he who concluded Japan's treaties with the foreign powers in 1858 . Cf. Papinot, op. cit., pp. $223^{-4}$. 
the Kyōto court, supported "Prince" Kishū, ${ }^{24}$ a rival claimant to the Edo office. When at last Tokugawa Iesada died [1 858], this "Prince" Kishū succeeded him, taking the name Tokugawa Iemochi. One of the first acts of the new ruler, performed at the suggestion of Ii Naosuke, was to reprimand the four lords of Owari, ${ }^{25}$ Mito, Tosa, and Echizen, to order them confined to their residences, ${ }^{26}$ and to have many of their retainers seized.

Sanai, knowing that he would meet a similiar fate, determined to commit bara-kiri, ${ }^{27}$ but refrained from doing so because of the admonition of his imprisoned lord . . . Finally one night, early in the tenth month of 1859 , police of the Edo government searched his home and confiscated his letters and other writings. The following day he was summoned to court and imprisoned, and a few days later was put to death.

In a brief appendix to the original manuscript there are a few bibliographical notes pertaining to Sanai's various literary efforts in the fields of foreign trade, education, and agriculture, as well as a list of biographical materials on the life of Sanai. There is also a note to the effect that when the Emperor Meiji made a tour through the northern coast provinces of Japan in 1878 , he made a stop at Fukui. At that time Sanai's relatives were received in imperial audience and granted a sum of money towards the celebration of Sanai's anniversary. In I 885 this same emperor contributed to the erection of a monument to Sanai in the Senju district of Tōkyō and, in I89I, conferred the senior grade of the Fourth Court Rank upon the deceased patriot. Thus was the name of Hashimoto Sanai restored to its rightful place among Japan's honored sons.

\footnotetext{
${ }^{24} \mathrm{Kish}$ is the Chinese name for the Japanese province of Kii, which is situated in the south central part of the main island. The Kii family was an even older branch of the Tokugawa than was the Hitotsubashi; however, the "Prince" of Kii (who is called Kishū above) was then only twelve years old and could scarcely be expected to challenge Naosuke's power.

${ }^{25}$ The province of Owari occupied the region around the present-day city of Nagoya.

${ }^{26}$ The manuscript fails to mention that Iesada, just before his death, also severely punished the lords of Mito, Owari, and Echizen for the same reasons suggested above: viz., attempting to restore the influence of the Kyöto court and daring to nominate their own candidate for the head of the Edo government. Cf. Murdoch, op. cit., III, 686-95.

${ }^{27}$ Hara-kiri (腹切), or “belly-cutting," is an ancient and honorable method of suicide, the right to which was formally reserved to those of the samurai class. Anyone taking his life in this manner spared both himself and his kin the dishonor which would otherwise have befallen them. In the above case his lord must have believed Sanai's life would be spared, else he most certainly would have encouraged the latter's resolve to avoid public execution.
} 